\title{
PENGEMBANGAN PERANGKAT PEMBELAJARAN MATEMATIKA MODEL KOOPERATIF DENGAN PENDEKATAN KOMBINASI EXPERIENCES, LANGUAGE, PICTORIAL, SYMBOL, APPLICATION (ELPSA) DAN SAINTIFIK
}

\author{
Muhammad Assaibin ${ }^{*}$, Hamzah Upu ${ }^{2}$, Muhammad Darwis ${ }^{3}$
}

\begin{abstract}
The research was Development Research with limited test which aimed to develop Mathematics learning devices with Cooperative Model with The Combination Of Experiences, Language, Pictorial, Symbol, Application (ELPSA) and Scientific Approach in Inequality Absolute Value, Fraction, and Irrational material which covered Lesson Plan, Students Book, and Students Worksheet. The subjects of the research were the students of class $X$ at SMAN 2 Polewali Mandar District with the total of 35 students. The Development procedure of the research employed Thiagarajan Model (4-D) which covered four stages, namely defining, design, development, and dissemination. The result of limited test showed that (1) the average score obtained by the students in learning result test is 75.42 from ideal score by 100 with deviation standard 8.69 where 29 from 35 students or $82.85 \%$ met individual completeness which shows that classical completeness had been reached; (2) by using Mathematics learning devices with Cooperative Model with the Combination of Experiences, Language, Pictorial, Symbol, Application (ELPSA) and Scientific Approach, the students are more active in the learning process; (3) in general, the students gave good responses on the learning devices used; and (4) the level of teacher' abilities in managing learning process of Cooperative Model with the Combination Of Experiences, Language, Pictorial, Symbol, Application (ELPSA) and Scientific Approach is in good category, meaning that the teachers' performances can be maintained. Based on the results of the research, it can concluded that Mathematics learning devices with Cooperative Model with the Combination Of Experiences, Language, Pictorial, Symbol, Application (ELPSA) and Scientific Approach developed has met the requirement of valid, effective, and practical criteria.
\end{abstract}

Keywords: Development, Combination of ELPSA, Scientifics

*) Prodi Pendidikan Matematika, Universitas Al Asyariah Mandar. 
E-mail:_muhammad.assaibin89@gmail.com

\section{PENDAHULUAN}

Matematika memiliki peran penting sebagai ilmu universal yang mendasari perkembangan teknologi modern dalam dunia pendidikan. Penerapan matematika akhir-akhir ini menjadi kunci simbolis dalam merangcang produkproduk media. Sehingga penerapan matematika kembali dikembangkan melalui teknologi elektronik dalam dunia kerja yang mempunyai peran penting dalam berbagai disiplin dan mengembangkan daya pikir manusia. Untuk menguasai dan menciptakan teknologi diperlukan penguasaan matematika yang kuat sejak dini.

Menurut Widdhiharto (Dewati, 2013), tujuan pembelajaran matematika adalah terbentuknya kemampuan bernalar pada diri siswa yang tercermin melalui kemampuan berpikir kritis, logis, dan sistematis dan memiliki sifat objektif, jujur, disiplin dalam memecahkan suatu permasalahan baik dalam bidang matematika, bidang lain maupun dalam kehidupan sehari-hari, sehingga pada pembelajaran matematika dibutuhkan suatu pemahaman konsep matematika yang matang agar siswa dapat memahami suatu konsep dalam bidang matematika dengan baik.

Lebih lanjut Muhammad Arif Tiro (2010) menggambarkan tentang pendidikan matematika.

1. Matematika sebagai Alat. Untuk pendidikan matematika, nilai penddikannya akan bergantung pada cirri matematika itu sendiri. Dalam posisi itu, matematika berfungsi sebagai wahana untuk mencapai tujuan pendidikan.

2. Matematika sebagai Metode Berfikir. Suatu sifat yang dapat diraih dari matematika adalah sifat ketaatan dan kepatuhan pada hokum. Matematika memiliki ketegasan tentang nilai benar dan salah. Misalnya kita dapat menerapkan cara matematika membenarkan atau menyalahkan suatu tindakan, semata-mata berdasarkan hukum-hukum yang diterima kebenarannya tanpa menghiraukan hukum-hukum lain di luar perangkat aksioma yang digunakan.

3. Matematika di Sekolah. Agar supaya pembudayaan nalar dapat dicapai, penyajian matematika sekolah baik dalam proses pembelajaran maupun dalam sajian buku ajar perlu mengarahkan kepada penataan nalar siswa. Bahan ajar perlu dikelola sehingga lebih tajam menata nalar siswa. hal ini berakibat kepada guru, bahwa mereka harus kreatif dalam melaksanakan pembelajaran. Guru tidak hanya menyelesaikan matreri kurikulum, tetapi mencermati dan mengevaluasi ketercapaian tujuan yang ingin dicapai dengan kurikulum tersebut. 
Model pembelajaran kooperatif (cooperatif learning) merupakan bentuk pembelajaran dengan cara siswa belajar dan bekerja dalam kelompok-kelompok kecil secara kolaboratif yang anggotanya terdiri dari empat sampai enam orang dengan struktur kelompok yang heterogen. Dalam pembelajaran ini akan tercipta sebuah interaksi yang lebih luas, yaitu interaksi dan komunikasi yang dilakukan antara guru dengan siswa, siswa dengan siswa, dan siswa dengan guru (multy way traffic communication) (Rusman, 2012).

ELPSA merupakan sebuah kerangka desain pembelajaran yang dibuat secara khusus untuk konteks Indonesia sebagai hasil dari analisis data video TIMSS (Thrends International Mathematics Science Study) (Lowrie \& Patahudin, 2015).

1. Experiences (E). Pengalaman mempertimbangkan bagaimana para siswa menggunakan matematika selama ini, konsep apa saja yang mereka ketahui, bagaimana mereka dapat memperoleh informasi, dan bagaimana matematika itu telah dialami oleh individu siswa baik di dalam maupun di luar kelas.

2. Language (L). Dalam matematika, bahasa matematika bisa bersifat umum maupun khusus.

3. Pictorial (P). Representasi gambar, merupakan kegiatan pembelajaran yang memberikan pengalaman mengenal konsep matematika dalam bentuk gambar.

4. Symbols (S). Representasi simbol, merupakan kegiatan pembelajaran yang dapat mengubah atau melakukan transisi dari representasi gambar ke representasi simbol.

5. Application (A). Aplikasi pengetahuan, merupakan kegiatan pembelajaran yang berusaha memahami signifikansi proses belajar dengan mengaplikasikan pengetahuan baru dalam memecahkan masalah dalam konteks yang bermakna.

Hosnan (Ningsih, 2015: 21) pembelajaran dengan metode saintifik memiliki karakteristik sebagai berikut.

1. Berpusat pada siswa

2. Melibatkan keterampilan proses sains dalam mengonstruksi konsep, hukum atau prinsip.

3. Melibatkan proses-proses kognitif yang potensial dalam merangsang perkembangan intelek, khususnya keterampilan berpikir tingkat tinggi siswa.

4. Dapat mengembangkan karakter siswa. 
Adapun penjelasan kegiatan belajar berdasarkan langkah-langkah pembelajaran dengan pendekatan saintifik dapat dilihat pada tabel 1 sebagai berikut:

Tabel 1. Langkah-langkah Pembelajaran Pendekatan Saintifik

\begin{tabular}{ll}
\hline \multicolumn{1}{c}{ Langkah Pembelajaran } & \multicolumn{1}{c}{ Kegiatan Belajar } \\
\hline Mengamati & $\begin{array}{l}\text { Membaca, mendengar, menyimak, melihat } \\
\text { (tanpa atau dengan alat) }\end{array}$ \\
Menanya & $\begin{array}{l}\text { Mengajukan pertanyaan tentang informasi yang } \\
\text { tidak dipahami dari apa yang diamati atau } \\
\text { pertanyaan untuk mendapatkan informasi }\end{array}$ \\
& tambahan tentang apa yang diamati (dimulai \\
& dari pertanyaan faktual sampai ke pertanyaan \\
& yang bersifat hipotetik) \\
Melakukan eksperimen, Membaca sumber lain \\
Informasi/Eksperimen & selain buku teks, Mengamati objek/ kejadian, \\
& Aktivitas, dan Wawancara dengan nara sumber. \\
Mengasosiasikan & Mengolah informasi yang sudah dikumpulkan \\
atau mengolah informasi & baik terbatas dari hasil kegiatan \\
& mengumpulkan/eksperimen mau pun hasil dari \\
& kegiatan mengamati dan kegiatan \\
& mengumpulkan informasi. \\
& Pengolahan informasi yang dikumpulkan dari \\
& yang bersifat menambah keluasan dan \\
kedalaman sampai kepada pengolahan & informasi yang bersifat mencari solusi dari \\
berbagai sumber yang memiliki pendapat yang \\
berbeda sampai kepada yang bertentangan \\
Menyampaikan hasil pengamatan, kesimpulan \\
berdasarkan hasil analisis secara lisan, tertulis, \\
ataumedia lainnya
\end{tabular}

Adapun langkah-langkah pembelajaran yang menggunakan Model Kooperatif dengan Pendekatan Kombinasi ELPSA dan Saintifik dapat dilihat pada tabel 2 sebagai berikut:

Tabel 2. Pembelajaran Model Kooperatif dengan Pendekatan Kombinasi

ELPSA dan Saintifik. 


\begin{tabular}{|c|c|c|}
\hline $\begin{array}{c}\text { Pembelajaran Model } \\
\text { Kooperatif }\end{array}$ & Pendekatan ELPSA & Pendekatan Saintifik \\
\hline \multicolumn{3}{|l|}{$\begin{array}{l}\text { Menyampaikan tujuan dan } \\
\text { memotivasi siswa }\end{array}$} \\
\hline Menyajikan informasi & $\begin{array}{l}\text { Experiences, } \\
\text { Language }\end{array}$ & Mengamati, Menanya \\
\hline \multicolumn{3}{|c|}{$\begin{array}{l}\text { Mengorganisasikan siswa ke } \\
\text { dalam kelompok kooperatif }\end{array}$} \\
\hline $\begin{array}{l}\text { Membimbing kelompok } \\
\text { bekerja dan belajar }\end{array}$ & Pictorial & $\begin{array}{l}\text { Mengumpulkan } \\
\text { Informasi }\end{array}$ \\
\hline Evaluasi & Symbols, Application & $\begin{array}{l}\text { Mengasosiasikan, } \\
\text { Mengkomunikasikan, }\end{array}$ \\
\hline Memberikan penghargaan & & \\
\hline
\end{tabular}

Oleh karena itu, penulis termotivasi untuk melakukan penelitian dengan judul "Pengembangan Perangkat Pembelajaran Matematika Model Kooperatif dengan Pendekatan Kombinasi ELPSA dan Saintifik pada Siswa Kelas X SMA Negeri 2 Kabupaten Polewali Mandar".

\section{METODE PENELITIAN}

\section{Jenis Penelitian}

Jenis penelitian ini adalah penelitian pengembangan (Research and Development) yang digunakan untuk menghasilkan produk tertentu dan menguji kevalidan, kepraktisan, dan keefektifan produk tersebut. Penelitian ini bertujuan untuk mengembangkan perangkat pembelajaran dalam Model Kooperatif dengan Pendekatan Kombinasi ELPSA dan Saintifik yang terdiri dari Rencana Pelaksanaan Pembelajaran (RPP), Lembar Kerja Siswa (LKS), Buku Siswa (BS), dan Tes Hasil Belajar (THB).

\section{Subjek Penelitian}

Penelitian ini dilaksanakan di SMA Negeri 2 kabupaten Polewali Mandar tahun pelajaran 2016/2017, subjek penelitian ini adalah siswa kelas X SMA.

\section{Instrumen Penelitian}

1. Lembar Pengamatan Aktivitas Siswa

Instrument ini bertujuan untuk memperoleh data aktivitas siswa selama proses pembelajaran berlansung untuk memperoleh data tentang aktivitas siswa berupa jumlah frekuensi jenis aktivitas siswa di kelas selama proses pembelajaran berlangsung. 
2. Lembar Pengamatan Pengelolaan Pembelajaran

Instrument ini digunakan untuk melihat keterlaksanaan Rencana Pelaksanaan Pembelajaran yang telah disusun serta untuk mengamati kemampuan guru dalam mengelola proses pembelajaran.

3. Angket Respon Siswa tentang Proses Pembelajaran

Hasil angket ini digunakan sebagai bahan pertimbangan untuk memperbaiki perangkat pembelajaran. Respon yang ditanyakan meliputi pendapat maupun komentar siswa terhadap materi pelajaran, kegiatan pelajaran dan perangkat pembelajaran.

4. Tes Hasil Belajar Matematika

Tes hasil belajar matematika dalam penelitian ini bertujuan untuk mengetahui tingkat penguasaan akademik siswa terhadap materi yang telah diajarkan. Tes tersebut disusun berdasarkan standar kompetensi diturunkan ke kompetensi dasar hingga tujuan pembelajaran yang akan dicapai kemudian diberikan kepada siswa.

5. Angket Respon Guru tentang Proses Pembelajaran

Angket respon guru terhadap proses pembelajaran ini, dapat berupa pendapat atau komentar guru terhadap materi pembelajaran, kegiatan pembelajaran, dan perangkat pembelajaran yang digunakan.

\section{Prosedur Penelitian}

Prosedur penelitian yang digunakan dengan adaptasi dan modifikasi pengembangan Four-D Model yang dikembangkan oleh Thiagarajan dan Semmel (1974) dalam Trianto (2012). Four-D Model yang meliputi empat tahap pengembangan, yaitu ; pertama pendefinisian (Define), kedua perancangan (Design), ketiga pengembangan (Develop), dan keempat penyebaran (Disseminate).

1. Tahap Pendefinisian (define)

Dalam tahap pendefinisian peneliti hanya bertujuan untuk menetapkan dan mendefinisikan syarat-syarat pembelajaran yang meliputi tujuan pembelajaran dan pembatasan materi dalam pembelajaran, diantaranya: Analisis Ujung Depan, Analisis siswa, Analisis Konsep, Analisis Tugas, dan Perumusan Tujuan Pembelajaran.

2. Tahap Perancangan (Design)

Diantaranya: Penyusunan Tes Acuan Patokan, Pemilihan Media, Pemilihan Format, dan Perancangan Awal Perangkat Pembelajaran.

3. Tahap Pengembangan (Develop)

a. Validasi Ahli/Praktisi 
Perangkat pembelajaran draft I yang telah dihasilkan pada tahap perancangan, dilakukan penilaian oleh para ahli/praktisi. Penilaian para ahli/praktisi terhadap perangkat pembelajaran mencakup: format, bahasa, ilustrasi dan isi. Perangkat pembelajaran yang telah direvisi maka diperoleh perangkat pembelajaran draf II.

b. Uji Coba Terbatas

Perangkat yang telah direvisi yakni draf II, siap untuk diujicobakan. Ujicoba dilakukan hanya pada satu kelas saja. Hal ini bertujuan untuk mendapatkan masukan dari siswa dan guru di lapangan. Data yang dihasilkan digunakan untuk melakukan revisi terhadap perangkat Draf II sehingga diperoleh Draf III.

Gambar 1. Desain Pengembangan Perangkat Pembelajaran

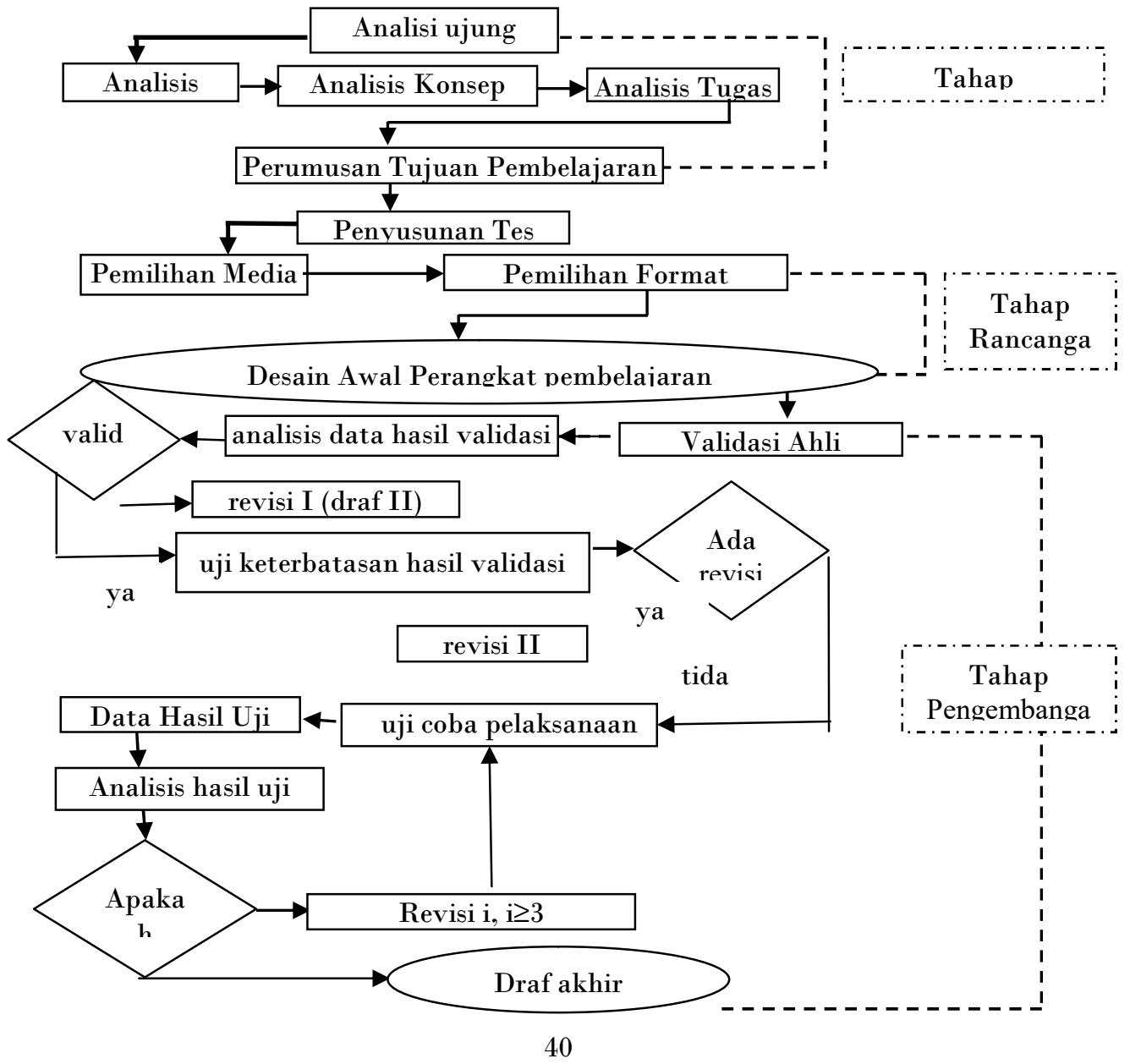




\section{HASIL DAN PEMBAHASAN}

HASIL

\section{Hasil Tahap Pendefinisian (Define)}

a. Hasil Analisis Ujung-Depan

Analisis Ujung-Depan bertujuan untuk mengidentifikasi masalah esensial yang dihadapi oleh guru dalam meningkatkan hasil belajar siswa. Berdasarkan pengamatan, diperoleh informasi bahwa masalah mendasar yang perlu diupayakan pemecahannya adalah cara penyajian bahan pelajaran yang kurang memberikan pemahaman siswa tentang inti dari materi pembelajaran khususnya pada materi pertidaksamaan nilai mutlak, pecahan dan irrasional, ditambah lagi suasana pembelajaran yang tidak menyenangkan, siswa lebih cenderung individual dalam menyelesaiakan masalah, tidak berbagi pemahaman kepada teman lain, kurang mampunyai rasa untuk saling menghargai pendapat temannya, tidak ingin berusaha lebih giat dalam menyelesaikan tugas.

b. Hasil analisis siswa

Latar belakang pengetahuan siswa yang terkait dengan materi pertidaksamaan nilai mutlak, pecahan dan irrasional pada kelas X indeks 2 SMA belum mereka pelajari namun telah diberikan proses pembelajaran awal dengan menguji cobakan perangkat pembelajaran untuk selanjutnya dilakukan validasi yang akurat.

c. Hasil analisis konsep

Bagian selanjutnya adalah kegiatan analisis konsep, pada tahap ini adalah mengidentifikasi, merinci, dan menyusun secara sistematis materi-materi utama yang dipelajari siswa. Selanjutnya materi tersebut disusun secara hirarkis. Materi pelajaran dalam penelitian ini adalah materi pertidaksamaan nilai mutlak, pecahan dan irrasional sesuai dengan Kompetensi Inti dalam Kurikulum K13. Garis besar materi pada penelitian ini adalah pertidaksamaan nilai mutlak, pecahan dan irrasional dengan indikator-indikator ketercapaian.

d. Hasil analisis tugas

Hasil analisis tugas untuk materi pada penelitian ini adalah pertidaksamaan nilai mutlak, pecahan dan irrasional dengan indikator-indikator ketercapaian antara lain : memahami konsep dan mampu mendeskripsikan pertidaksamaan nilai mutlak, memahami konsep dan mampu mendeskripsikan pertidaksamaan pecahan, memahami konsep dan mampu mendeskripsikan pertidaksamaan irrasional serta mampu menyelesaiakan himpunan penyelesaiannya.

e. Hasil analisis spesifikasi tujuan pembelajaran 
Perincian indikator dan tujuan pembelajaran pada materi pertidaksamaan nilai mutlak, pecahan dan irrasional didasarkan pada kompetensi inti dan kompetensi dasar.

\section{Hasil Tahap Perancangan (Design)}

a. Penyusunan Tes

Penyusunan tes didasarkan pada analisis materi dan analisis tugas yang dijabarkan dalam indikator pencapaian. Tes yang dimaksud adalah tes hasil belajar pada materi pertidaksamaan nilai mutlak, pecahan dan irrasional.

b. Hasil Pemilihan Media

Proses pemilihan media disesuaikan dengan analisis materi, analisis tugas, dan karakteristik siswa. Dari hasil pemilihan media ini, ditentukan bahwa media pembelajaran yang diperlukan dalam pelaksanaan pembelajaran matematika Model Kooperatif dengan Pendekatan Kombinasi ELPSA dan Saintifik adalah perangkat pembelajaran, diantaranya: (1) Rencana Pelaksanaan Pembelajaran, (2) Buku siswa , (3) Lembar Kegiatan Siswa, (4) Tes Hasil Belajar. Serta alat bantu pembelajaran yang terdiri atas: (1) papan tulis, (2) spidol, (3) penghapus, (4) Laptop dan LCD.

c. Hasil Pemilihan Format

Pemilihan format perangkat pembelajaran bertujuan untuk memilih format untuk mendesain atau merancang perangkat pembelajaran, pemilihan strategi, pendekatan, metode pembelajaran dan sumber belajar.

1. Rencana Pelaksanaan Pembelajaran (RPP) dengan Pembelajaran Model

Kooperatif dengan Pendekatan Kombinasi ELPSA dan Saintifik

Langkah-langkah yang dilakukan dalam penyusunan rencana pelaksanaan pembelajaran meliputi: (1) menentukan identitas mata pelajaran dan tingkat satuan pendidikan, (2) menentukan alokasi waktu, (3) menentukan standar kompetensi dan kompetensi inti, (4) menentukan indikator pencapaian dalam hal ini indikator kognitif proses dan indikator pencapaian afektif, (5) merumuskan tujuan pembelajaran berdasarkan indikator yang telah ditentukan (indikator kognitif proses dan indikator afektif), (6) Menentukan materi pembelajaran yang mencakup materi prasyarat dan materi ajar, (7) menentukan model, strategi dan metode yang akan digunakan, (8) merumuskan langkahlangkah pembelajaran yang terdiri atas kegiatan awal, kegiatan inti, dan kegiatan akhir dengan mengintegrasikan nilai-nilai budaya yang sesuai pada setiap kegiatan tersebut, (9) menentukan sumber dan bahan yang digunakan selama proses pembelajaran berlangsung, (10) merumuskan format penilaian yang terbagi menjadi dua aspek, yakni aspek kognitif dan aspek afektif (karakter dan keterampilan sosial). 
2. Lembar Kegiatan Siswa (LKS) dengan Model Kooperatif dengan Pendekatan Kombinasi ELPSA dan Saintifik.

Pada setiap lembar kegiatan siswa yang dirancang, akan diberikan petunjuk kepada siswa untuk selalu berdiskusi mencari pemecahan masalah pada lembar kegiatan siswa tersebut dengan memperhatikan betapa pentingnya kerja sama dan menyelesaikannya dengan penuh rasa senang.

3. Tes Hasil Belajar

Soal-soal disusun dalam bentuk soal uraian. Komponen tes hasil belajar meliputi kisi-kisi, soal tes, rubrik penskoran (kunci jawaban).

d. Hasil Perancangan Awal

Selanjutnya dalam proses pengembangan draft ini disebut draft awal. Draft awal ini kemudian dilanjutkan pada tahap pengembangan untuk divalidasi dan dilakukan revisi.

\section{Hasil Tahap Pengembangan (Develop)}

Tahap pengembangan adalah tahap lanjutan dari tahap pendefinisian dan tahap perancangan dan merupakan tahapan ketiga dari Model 4-D. Deskripsi Penilaian Ahli terhadap Perangkat Pembelajaran

Tabel 3. Deskripsi Hasil Penilaian Ahli terhadap Perangkat Pembelajaran

\begin{tabular}{lllll}
\hline \multicolumn{1}{c}{ Perangkat } & \multicolumn{1}{c}{ Indikator } & \multicolumn{2}{c}{ Penilaian } & Keterangan \\
\hline \multirow{2}{*}{ RPP } & 1. & Kompetensi Dasar dan & 4 & Valid \\
& 2. & Indikator & 4 & Valid \\
& 3. & Kelengkapan & 4.50 & Sangat Valid \\
& 4. & Materi Pembelajaran & 4.50 & Sangat Valid \\
& 5. & Skenario & 4.07 & Valid \\
& 6. & Assesmen & 4.50 & Sangat Valid \\
& 7. & Bahasa & 4.00 & Valid \\
Buku siswa & \multicolumn{2}{c}{ Rata-Rata } & 4.22 & Valid \\
& 1. & Format dan Komponen & 4 & Valid \\
& 2. & Isi & 4.10 & Valid \\
& 3. & Bahasa & 4 & Valid \\
LKS & \multicolumn{2}{c}{ Rata-Rata } & 4.03 & Valid \\
& 1. & Format & 4 & Valid \\
& 2. & Isi & 3.84 & Valid \\
& 3. & Bahasa & 4 & Valid
\end{tabular}




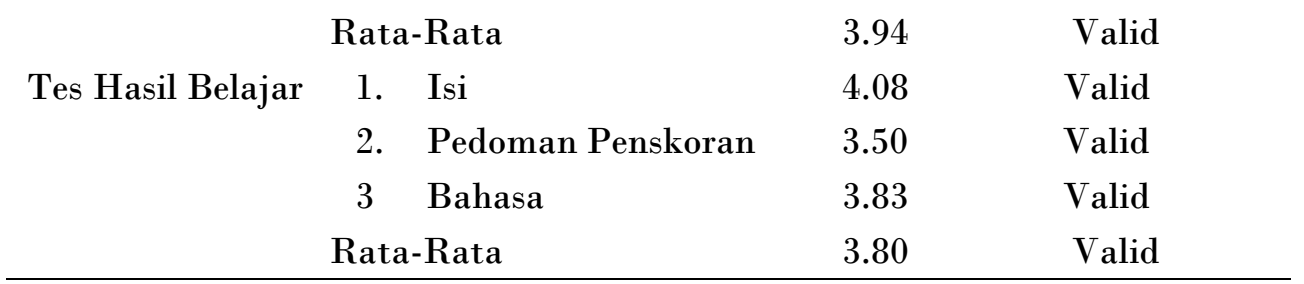

b. Deskripsi hasil uji coba perangkat pembelajaran

1. Analisis kepraktisan

Tabel 4. Hasil perhitungan koefisien reliabilitas instrumen lembar observasi pengelolaan pembelajaran

\begin{tabular}{cccccc}
\hline $\begin{array}{c}\text { Pertemuan } \\
\text { ke... }\end{array}$ & I & II & III & IV & V \\
\hline Reliabilitas & $\mathbf{8 7 , 1 0 \%}$ & $\mathbf{8 7 , 1 0 \%}$ & $96,77 \%$ & $93,55 \%$ & $90,32 \%$ \\
\hline
\end{tabular}

a) Deskripsi hasil pengamatan aktivitas siswa

Tabel 5. Rekapitulasi aktivitas siswa

\begin{tabular}{|c|c|c|c|c|c|c|c|c|}
\hline \multirow[t]{2}{*}{ No } & \multirow{2}{*}{$\begin{array}{c}\text { Aspek } \\
\text { Pengamatan } \\
\text { Aktivitas Siswa }\end{array}$} & \multicolumn{5}{|c|}{$\begin{array}{c}\text { Persentase Aktivitas Siswa pada } \\
\text { Pertemuan ke... }\end{array}$} & \multirow{2}{*}{$\begin{array}{l}\text { Rata-rata } \\
\text { Persentase } \\
\text { aktivitas } \\
\text { siswa }\end{array}$} & \multirow{2}{*}{$\begin{array}{c}\text { Interval } \\
\text { Toleran } \\
\text { si PWI } \\
(\%)\end{array}$} \\
\hline & & 1 & 2 & 3 & 4 & 5 & & \\
\hline 1 & $\begin{array}{l}\text { Mengamati dan } \\
\text { mengaitkan } \\
\text { informasi dan } \\
\text { mencatat } \\
\text { seperlunya. }\end{array}$ & 10.00 & 12.22 & 8.89 & 11.11 & 11.11 & 10.67 & $7-17$ \\
\hline 2 & $\begin{array}{l}\text { Memperhatikan } \\
\text { bahasa, pictorial, } \\
\text { symbols lalu } \\
\text { menanyakannya. }\end{array}$ & 11.11 & 11.11 & 13.33 & 13.33 & 12.22 & 12.22 & $5-15$ \\
\hline 3 & $\begin{array}{l}\text { Mengumpulkan } \\
\text { informasi dan } \\
\text { aktif berdiskusi. }\end{array}$ & 12.22 & 13.33 & 12.22 & 12.22 & 12.22 & 12.44 & $3-13$ \\
\hline 4 & Mengajukan & 20.00 & 18.89 & 17.78 & 18.89 & 20.00 & 19.11 & $23-33$ \\
\hline
\end{tabular}


pertanyaan

kepada teman

dan guru.

5 Mengerjakan

lembar kerja

13.3

siswa.

$\begin{array}{lllllll}3.33 & 15.56 & 16.67 & 16.67 & 16.67 & \mathbf{1 5 . 7 8} & 9-19\end{array}$

6 Mengasosiasikan informasi yang

$\begin{array}{lllllll}17.78 & 13.33 & 14.44 & 13.33 & 13.33 & \mathbf{1 4 . 4 4} & 9-19\end{array}$ telah diperoleh.

7 Mengkomunikasi kan tentang penemuannya kepada guru / teman.

8 kegiatan lain di luar tugas, misalnya tidak memperhatikan penjelasan guru, mengerjakan tugas mata pelajaran lain.

Aktivitas yang tidak berkaitan dengan KBM (ngantuk, tidur, ngobrol, melamun, dsb)

b) Deskripsi hasil respons siswa

Tabel 6. Deskripsi Hasil Respons Siswa terhadap Perangkat dan Pelaksanaan Pembelajaran

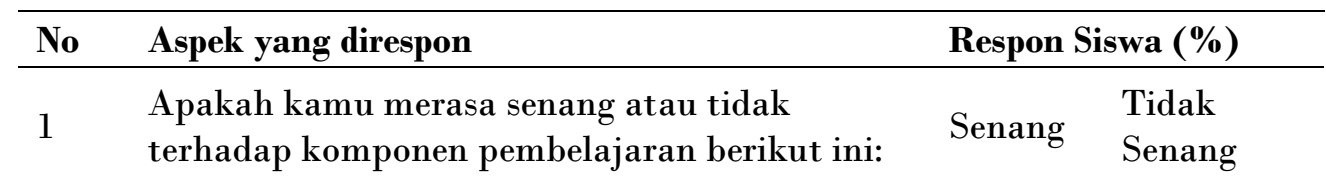




\begin{tabular}{|c|c|c|c|}
\hline \multicolumn{2}{|c|}{ a. Suasana pembelajaran di kelas } & 100.00 & 0.00 \\
\hline & b. Cara guru mengajar & 94.29 & 5.71 \\
\hline & c. Buku siswa & 100.00 & 0.00 \\
\hline & d. Lembar Kegiatan Siswa (LKS) & 100.00 & 0.00 \\
\hline & e. Tes hasil belajar & 94.29 & 5.71 \\
\hline & Persentase Rata-rata & 97.71 & 2.29 \\
\hline \multirow{7}{*}{2} & $\begin{array}{l}\text { Apakah komponen pembelajaran berikut ini } \\
\text { bagimu, baru atau tidak: }\end{array}$ & Baru & $\begin{array}{l}\text { Tidak } \\
\text { Baru }\end{array}$ \\
\hline & a. Suasana pembelajaran di kelas & 91.43 & 8.57 \\
\hline & b. Cara guru mengajar & 80.00 & 20.00 \\
\hline & c. Materi pelajaran & 25.71 & 74.29 \\
\hline & d. Buku siswa & 100.00 & 0.00 \\
\hline & e. Tes hasil belajar & 100.00 & 0.00 \\
\hline & Persentase Rata-rata & 79.43 & 20.57 \\
\hline \multirow{6}{*}{3} & $\begin{array}{l}\text { Apakah kamu dapat memahami dengan jelas } \\
\text { atau tidak bahasa yang digunakan dalam: }\end{array}$ & Jelas & Tidak jelas \\
\hline & a. Guru dalam menjelaskan & 100.00 & 0.00 \\
\hline & b. Buku siswa & 94.29 & 5.71 \\
\hline & c. Lembar Kegiatan Siswa (LKS) & 97.14 & 2.86 \\
\hline & d. Tes hasil belajar & 91.43 & 8.57 \\
\hline & Persentase Rata-rata & 95.71 & 4.29 \\
\hline \multirow{5}{*}{4} & $\begin{array}{l}\text { Apakah kamu tertarik atau tidak dengan } \\
\text { penampilan (tulisan/ilustrasi/gambar/letak } \\
\text { gambar) yang terdapat dalam: }\end{array}$ & Tertarik & $\begin{array}{l}\text { Tidak } \\
\text { tertarik }\end{array}$ \\
\hline & a. Buku siswa & 94.29 & 5.71 \\
\hline & b. Lembar Kegiatan Siswa (LKS) & 94.29 & 5.71 \\
\hline & c. Tes hasil belajar & 91.43 & 8.57 \\
\hline & Persentase Rata-rata & 93.33 & 6.67 \\
\hline
\end{tabular}


Lanjutan Tabel 6. Deskripsi Hasil Respons Siswa terhadap Perangkat dan Pelaksanaan Pembelajaran

\begin{tabular}{|c|c|c|c|}
\hline No & Aspek yang direspons & \multicolumn{2}{|c|}{ Respons Siswa (\%) } \\
\hline 5 & $\begin{array}{l}\text { Apakah kamu berminat atau tidak untuk } \\
\text { mengikuti pembelajaran selanjutnya, seperti } \\
\text { yang baru saja kamu ikuti? }\end{array}$ & Berminat & $\begin{array}{c}\text { Tidak } \\
\text { Berminat } \\
0.00\end{array}$ \\
\hline 6 & $\begin{array}{l}\text { Apakah ada kemajuan yang kamu rasakan } \\
\text { setelah pembelajaran ini? (seperti mudah } \\
\text { memahami, bersemangat dalam belajar, lebih } \\
\text { bertanggung jawab pada tugas, mampu } \\
\text { mengkomunikasikan ide dan bekerjasama, dll), } \\
\text { jelaskan jawabanmu! }\end{array}$ & $\begin{array}{c}\text { Ada } \\
\text { Kemajuan }\end{array}$ & $\begin{array}{l}\text { Tidak ada } \\
\text { Kemajuan }\end{array}$ \\
\hline \multirow[t]{2}{*}{7} & $\begin{array}{l}\text { Bagaimana pendapatmu tentang kegiatan } \\
\text { belajar mengajar dengan menggunakan } \\
\text { perangkat pembelajaran matematika yang }\end{array}$ & $\begin{array}{l}\text { Tanggapan } \\
\text { Positif }\end{array}$ & $\begin{array}{l}\text { Tanggapan } \\
\text { Negatif }\end{array}$ \\
\hline & $\begin{array}{l}\text { telah kamu gunakan selama proses } \\
\text { pembelajaran? }\end{array}$ & 100.00 & 0.00 \\
\hline \multirow[t]{3}{*}{8} & $\begin{array}{l}\text { Apakah kamu setuju jika dalam proses } \\
\text { pembelajaran guru menggunakan perangkat }\end{array}$ & Setuju & $\begin{array}{l}\text { Tidak } \\
\text { Setuju }\end{array}$ \\
\hline & $\begin{array}{l}\text { pembelajaran matematika seperti yang kalian } \\
\text { gunakan selama proses }\end{array}$ & 100.00 & 0.00 \\
\hline & Persentase Rata-rata & 95.77 & 4.23 \\
\hline
\end{tabular}

c) Deskripsi Hasil Respon Guru

Tabel 7. Deskripsi Hasil Respons Guru terhadap Perangkat dan Pelaksanaan Pembelajaran

\begin{tabular}{clcc}
\hline No & \multicolumn{1}{c}{ Aspek yang direspon } & \multicolumn{2}{c}{ Respon Guru (\%) } \\
\hline 1 & $\begin{array}{l}\text { Apakah kamu merasa senang atau tidak } \\
\text { terhadap komponen pembelajaran berikut ini: }\end{array}$ & Senang & Tidak \\
a. Rencana Pelaksanaan Pembelajaran (RPP) & 100 & 0 \\
& b. Angket Aktivitas Siswa dan Respon Siswa & 100 & 0 \\
& c. Buku Siswa (BS) & 100 & 0 \\
& d. Lembar Kegiatan Siswa (LKS) & 100 & 0
\end{tabular}




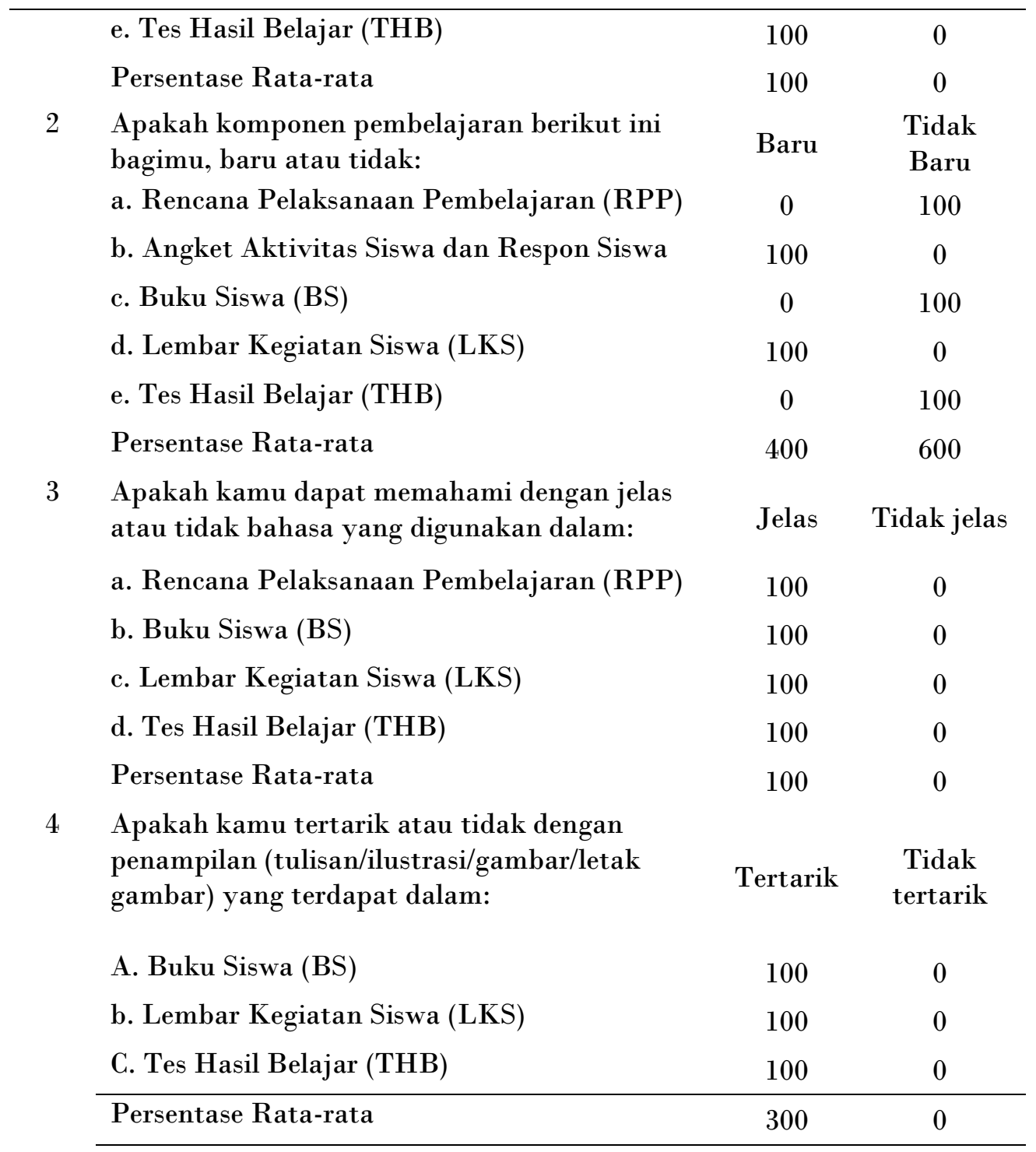

Lanjutan tabel 7. Deskripsi Hasil Respons Guru terhadap Perangkat dan Pelaksanaan Pembelajaran

\begin{tabular}{|c|c|c|}
\hline No & Aspek yang direspons & Respons Guru (\%) \\
\hline 5 & Apakah kamu berminat atau tidak untuk & Berminat \\
\hline
\end{tabular}


mengikuti pembelajaran selanjutnya, seperti yang baru saja lakukan?

6 Apakah ada kemajuan yang kamu rasakan setelah pembelajaran ini? (seperti mudah menjelaskan, bersemangat dalam mengajar, lebih bertanggung jawab, mampu mengkomunikasikan materi dengan mudah, dll), jelaskan jawabanmu!

7 Bagaimana pendapatmu tentang kegiatan belajar mengajar dengan menggunakan perangkat pembelajaran matematika yang telah kamu gunakan selama proses pembelajaran?

8 Apakah kamu setuju jika dalam proses pembelajaran yang kamu lakukan menggunakan perangkat pembelajaran ini?
Berminat

100

0

Ada Tidak ada

Kemajuan Kemajuan

100

0

Tanggapan

Positif

Tanggapan

Negatif

100

0

Setuju Tidak Setuju

$100 \quad 0$

92.50

7.50

d) Deskripsi Nilai Tes Hasil Belajar

Tabel 8. Statistik Nilai Hasil Belajar Matematika Siswa Kelas X SMA Negeri 2

\begin{tabular}{cc}
\hline Variabel & Nilai Statistik \\
\hline Subjek penelitian & 35 \\
Nilai ideal & 100 \\
Rata-rata & 75.42 \\
Standar deviasi & 8.69 \\
Rentang Nilai & 35 \\
Nilai maksimum & 95 \\
Nilai minimum & 60 \\
Jumlah Siswa yang Tuntas & 29 \\
Jumlah siswa yang Tidak Tuntas & 6 \\
\hline
\end{tabular}

Tabel 9. Distribusi Frekuensi dan Persentase Nilai Hasil Belajar Matematika Siswa Kelas X indeks 2 SMA negeri 2 Kabupaten Polewali Mandar 


\begin{tabular}{cccc}
\hline Nilai & Kategori & Frekuensi & Persentase \\
\hline $0-39$ & Sangat Rendah & 0 & $0 \%$ \\
$40-59$ & Rendah & 0 & $0 \%$ \\
$60-74$ & Sedang & 14 & $40 \%$ \\
$75-90$ & Tinggi & 20 & $57.140 \%$ \\
$91-100$ & Sangat Tinggi & 1 & $2.85 \%$ \\
\hline
\end{tabular}

Hasil belajar siswa dianalisis maka persentase ketuntasan hasil belajar siswa setelah diterapkan perangkat pembelajaran matematika Model Kooperatif dengan Pendekatan Kombinasi ELPSA dan Saintifik dapat dilihat pada Tabel 4.16 berikut:

Tabel 10. Deskripsi Ketuntasan Hasil Belajar Matematika

\begin{tabular}{cccc}
\hline Nilai & Kategori & Frekuensi & Persentase \\
\hline $0-65$ & Tidak Tuntas & 6 & $17.14 \%$ \\
$66-100$ & Tuntas & 29 & $82.85 \%$ \\
\hline
\end{tabular}

Hasil-hasil yang diperoleh di atas mengindikasikan bahwa pada uji coba yang dilakukan, perangkat pembelajaran telah memenuhi kriteria kevalidan, kepraktisan, dan keefektifan.

\section{Deskripsi Hasil Penyebaran}

Perangkat yang dihasilkan dalam pembelajaran Model Kooperatif dengan Pendekatan Kombinasi ELPSA dan Saintifik pada tahap akhir pengembangan, selanjutnya ingin dilakukan penyebaran atau disosialisasikan pada sekolah atau dinas pendidikan untuk kemudian dijadikan sebuah referensi tambahan dalam dunia akademi. Namun hal ini akan dilakukan peneliti pada kesempatan selanjutnya, karena tujuan akhir peneliti dalam penelitian ini tidak sampai pada tahap penyebaran.

\section{PEMBAHASAN}

1. Ketercapaian tujuan penelitian

a. Kevalidan

Berdasarkan pembahasan hasil revisi dan penilaian oleh validator yang dikemukakan sebelumnya dapat disimpulkan bahwa perangkat yang telah dikembangkan diantaranya: Rencana Pelaksanaan Pembelajaran (RPP), Buku siswa (BK), Lembar Kegiatan Siswa (LKS), dan Tes Hasil Belajar (THB) secara keseluruhan telah memenuhi kriteria kevalidan. 


\section{b. Keefektifan}

Untuk melihat keefektifan perangkat pembelajaran yang meliputi: (1) ketuntasan hasil belajar, (2) aktivitas siswa, dan (3) respon siswa dan (4) respon guru. Kriteria yang harus dipenuhi sehingga suatu perangkat pembelajaran dikatakan efektif adalah minimal memenuhi 2 kriteria tetapi indikator ketuntasan hasil belajar harus terpenuhi dan melihat indikator mana yang terpenuhi pada saat uji coba dilakukan, apakah aktivitas siswa atau respon siswa. Dari hasil uji coba yang dilakukan pada siswa kelas $\mathrm{X}$ indeks 2 SMA Negeri 2 Kabupaten Polewali Mandar keempat kriteria yang menuju keefektifan terpenuhi mulai dari (1) ketuntasan hasil belajar, (2) aktivitas siswa, dan (3) respon siswa, (4) pengelolaan pembelajaran Model Kooperatif dengan Pendekatan Kombinasi ELPSA dan Pendekatan Saintifik oleh guru respon guru, dan (5) respon guru.

c. Kepraktisan

Secara teroritis, hasil penilaian ahli dalam bidang pendidikan matematika terhadap perangkat pembelajaran matematika dengan Model Kooperatif dengan Pendekatan Kombinasi ELPSA dan Saintifik menyatakan bahwa perangkat yang telah dikembangkan layak untuk digunakan dalam proses pembelajaran. Sedangkan secara empirik, berdasarkan hasil pengamatan pengelolaan pembelajaran oleh observer atau pengamat menyatakan bahwa perangkat pembelajaran terlaksana dengan baik pada saat uji coba. Berdasarkan peninjauan teoritik dan penilaian validator serta hasil pengamat maka dapat disimpulkan bahwa perangkat pembelajaran memenuhi kriteria kepraktisan.

\section{SIMPULAN}

Untuk melihat hasil ujicoba perangkat pembelajaran matematika dengan Model Kooperatif dengan Pendekatan Kombinasi ELPSA dan Saintifik diperoleh skor rata-rata siswa pada tes hasil belajar adalah 75,42 dari skor ideal 100 dengan standar deviasi 8,69 dan banyaknya siswa yang tuntas belajar adalah 29 dari 35 orang siswa dan Kegiatan belajar mengajar yang dilakukan dengan menggunakan perangkat pembelajaran matematika dengan Model Kooperatif dengan Pendekatan Kombinasi ELPSA dan Saintifik menjadikan siswa lebih aktif dalam proses pembelajaran serta Guru mampu mengelola proses pembelajaran dengan menggunakan Model Kooperatif dengan Pendekatan Kombinasi ELPSA dan Saintifik. Hal ini terlihat pada tabel hasil pengamatan pengelolaan pembelajaran dimana sebagian besar aspek dapat terlaksana dengan baik. 
Tanggapan siswa terhadap perangkat pembelajaran matematika dengan Model Kooperatif dengan Pendekatan Kombinasi ELPSA dan Saintifik berupa Buku Siswa, Rencana Pelaksanaan Pembelajaran dan Lembar Kerja Siswa baik dan tanggapan guru terhadap perangkat pembelajaran matematika dengan Model Kooperatif dengan Pendekatan Kombinasi ELPSA dan Saintifik berupa Buku Siswa, Rencana Pelaksanaan Pembelajaran dan Lembar Kerja Siswa baik. Sehingga dapat disimpulkan perangkat pembelajaran matematika dalam Model Kooperatif dengan Pendekatan Kombinasi ELPSA dan Saintifik ini memenuhi kriteria kevalidan, keefektifan dan kepraktisan.

\section{SARAN}

Adapun saran dari peneliti sehubungan dengan penelitian yang telah dilakukan yaitu penelitian selanjutnya perangkat pembelajaran yang dihasilkan perlu diujicobakan secara meluas untuk melihat keunggulan perangkat pembelajaran matematika Model Kooperatif dengan Pendekatan Kombinasi ELPSA dan Saintifik dan Model pembelajaran matematika Model Kooperatif dengan Pendekatan Kombinasi ELPSA dan Saintifik dapat diterapkan oleh guru sebagai alternatif model pembelajaran yang dapat meningkatkan hasil belajar siswa serta guru sebaiknya senantiasa memperhatikan tingkat kognisi siswa dalam pemilihan model, pendekatan, metode dan strategi dalam memberikan susanana pembelajaran yang beradaptasi dengan keadaan siswa secara psikologi agar pembelajaran berjalan sesuai dengan harapan yang diinginkan sesuai dengan tujuan pembelajaran.

\section{DAFTAR PUSTAKA}

Anurrahman. 2009. Belajar dan Pembelajaran. Bandung: Alfabeta

Arsyad, Nurdin. 2016. Model Pembelajaran Menumbuhkan Kemampuan Metakognitif. Makassar: Pustaka Refleksi.

Ali, Muhammad. 2015. Pengembangan Perangkat Pembelajaran Matematika Model Kooperatif Tipe Student Teams Achievement Division (STAD) dengan Pendekatan Saintifik. Tesis. Tidak diterbitkan. Makassar: PPs UNM.

Alimin, Rismawati. 2014. Pengembangan Perangkat Pembelajaran Berbasis Masalah dengan Pendekatan Saintifik pada Pokok Bahasan Geometri untuk Peserta Didik SMA Kelas X. Tesis. Tidak diterbitkan. Makassar: PPs UNM. 
Arif Tiro, Muhammad. 2010. Cara Efektif Belajar Matematika. Makassar: Andira Publisher.

Abdullah, Ridwan. 2015. Pembelajaran Saintifik untuk Implementasi Kurikulum 2013. Jakarta: PT. Bumi Aksara.

Dewati, R \&dkk. . 2013. EfektifitasPenerapan Model Pembelajaran Learning Cycle 3 E dalam Pembelajaran Matematika. Universitas Lampung: Jurnal Pendidikan Matematika, Vol 2 No. 2.

Daryanto. 2013. Inovasi Pembelajaran Efektif. Bandung: Penerbit YramaWidya.

Huda, Miftahul. 2014. Cooperatif Learning Metode, Teknik, Struktur dan Model Mpenerapan. Yogyakarta. Pustaka Belajar.

Hudojo, Herman. 1990. Strategi Mengajar Belajar Matematika. Surabaya: IKIP Malang.

Hudojo, Herman. 2005. Pengembangan Kurikulum dan Pembelajaran Matematika. Surabaya: IKIP Malang.

Istiyah, Marwati, Asih. 2010. Media Pembelajaran. Jakarta: Multi Kreasi Satudelapan.

Kurnia, Novianto. 2013. Matematika SMA Kelas X. Jakrata Timur. Yudistira.

Kurniasih, Imas., Sani, Berlin.2014. Implementasi Kurikulum 2013 Konsep dan Penerapan. Surabaya: Kata Pena.

Kurniasih, I. dkk. 2014. Sukses Mengimplementasikan Kurikulum 2013. Penerbit Kata Pena .

Lowrie, T. 2014. Buku I Pengenalan Program: Bahan Belajar Geometri untuk guru Matenmatika SMP di MGMP. Jakarta: Bank Dunia.

Lowrie, T. \& Patahudin, S. M. 2015. ELPSA: Kerangka Kerja untuk Merancang Pembelajaran Matematika. Jurnal Didaktik Matematika, (Online), Vol.2, No.1 (http://jurnal.unsyiah.ac.id, Diakses 15 September 2015)

Niswani. 2015. Keefektifan Model Braind Based Learning dengan Pendekatan Saintifik dalam Pembelajaran Matematika pada Peserta Didik Siswa Kelas VIII SMP Negeri 4 Sungguminasa Kabupaten Gowa. Tesis Tidak Diterbitkan: PPS UNM Makasssar.

Nurdin, 2007. Model Pembelajaran Matematika yang Menumbuhkan Kemampuan Metakognitif untuk Menguasai Bahan Ajar. Disertasi. Tidak Diterbitkan. Surabaya: PPs UNESA.

Ningsih. 2015. Komparasi Pembelajaran Saintifik Setting Kooperatif Tipe STAD dan Pembelajaran Berbasis Masalah Ditinjau Dari Hasil Belajar Matematika Siswa Kelas VII SMP Negeri 6 Watampone. Tesis Tidak Diterbitkan: PPS UNM Makasssar. 
Nur Afifah, Rina. 2015. Pengembangan Perangkat Pembelajaran Matematika Melalui Model Pembelajaran Kooperatif dengan Kombinasi Pendekatan Saintifik dan Realistik pada siswa Kelas VII SMP Negeri 33 Bulukumba. TesisTidak Diterbitkan: PPS UNM Makasssar.

Paronda, Nimah. 2010. Keefektifan Pembelajaran Kooperatif tipe NHT dengan Pendekatan Problem Possing dalam Pembelajaran Matematika di SMP. Makassar: Tesis. Tidak diterbitkan. Makassar: PPs UNM.

Rusman. 2010. Model-Model Pembelajaran. Jakarta: PT Raja Grafindo Persada. 2012. Model-Model Pembelajaran. Jakarta: PT Raja Grafindo Persada.

Salmah. 2015. Pengembangan Perangkat Pembelajaran Berbasis Masalah dengan Pendekatan Saintifik pada Pokok Bahasan Himpunan untuk Peserta Didik Kelas VII SMP. Tesis Tidak diterbitkan. Makassar:Pasca sarjana-UNM

Sanjaya, Wina. 2005. Starategi Pembelajaran Berorientasi Standar Proses Pendidikan. Jakarta: Kencana Prenada Media Group.

Susanto, A. 2013. Teori Belajar dan Pembelajaran di Sekolah dasar. Jakarta:

Kencana Prenada Media Group.

Solihatin dan Raharjo. 2005. Cooperstive Learning. Jakarta: Bumi Aksara.

Suprihariningrum, J. 2012. Strategi Pembelajaran Teori \& Aplikasi. Yogyakarta: Ar-Ruzz Media.

Suherman, dkk. 2003. Strategi Pembelajaran Matematika Kontemporer. Bandung: Universitas Pendidikan Indonesia.

Sugandi, Achmad, dkk. 2004. Teori Pembelajaran. Semarang: UPT MKK UNNES.

Soedjadi. 2000. Kiat Pendidikan Matematika di Indonesia. Direktorat Jendral

Pendidikan Tinggi Departemen Pendidikan Nasional. Jakarta.

Slameto. 2010. Belajar dan Faktor-Faktor yang Mempengaruhinya. Jakarta: Rineka Cipta.

Sriyanti, Lilik. 2013. Psikologi Belajar. Yogyakarta: Ombak.

Suyono \& Hariyanto. 2014. Belajar dan Pembelajaran: Teori dan Konsep Dasar. Bandung: Remaja Rosdakarya.

Trianto. 2012. Mendesain Model Pembelajaran Inovatif-Progresif. Jakarta: Kencana Prenada Media Grup

Trianto: 2009. Mendesain Model Pembelajaran Inovatif-Progresif. Jakarta: Kencana Prenada Media Group.

Tran, V. D. 2014. The Effects of Cooperative Learning on the Academic Achievement and Knowledge Retention. International Journal of Higher Education, (Online), Vol. 3, No. 2. 
Vol. 15, No. 1, Mei 2019

p-ISSN: 2087-3476 | e-ISSN: 2541-5700

Jurnal Pendidikan PEPATUDZU

http://dx.doi.org/10.35329/fkip.v15il.313

Media Pendidikan dan Sosial Kemasyarakatan

Taniredja, Tukiran dan dkk. 2011. Model - model Pembelajaran Inovatif. Bandung. CV. Alfabeta

Taniredja, Tukiran dkk. 2014. Model-Model Pembelajaran Inovatif dan Efektif. Bandung: Alfabeta.

Tim Penyusun Kamus Pusat Pembinaan dan Pengembangan Bahasa. 2006. Kamus Besar Indonesia. Jakarta: Balai Pustaka.

Uno, Hamzah B. 2012. Model Pembelajaran Menciptakan Proses Belajar

Mengajar yang Kreatif dan Efektif. Jakarta. Bumi Aksara. 